\title{
Placental Lactogen Secretion during Prolonged-Pregnancy in the Rat: The Ovary Plays a Pivotal Role in the Control of Placental Function
}

\author{
Kunio SHIOTA, NAOKi FURUYAMA* ANd Michio TAKAHASHI* \\ Laboratories of Cellular Biochemistry and *Veterinary Physiology, \\ Veterinary Medical Science, The University of Tokyo, Tokyo 113, Japan
}

\begin{abstract}
The serum of rats at mid-pregnancy contains at least 2 distinct placental lactogen (PL)-like substances tentatively termed placental lactogen- $\alpha$ (PL- $\alpha$ ) and placental lactogen- $\beta$ (PL- $\beta$ ) (Endocrinol Japon 38: 533-540, 1991). We have investigated the secretory patterns of three placental lactogens (PL- $\alpha$, PL- $\beta$ and placental lactogen-II) during normal pregnancy and in two prolonged-pregnancy models. Pregnancy was prolonged by the introduction of new corpora lutea by inducing ovulation on day 15 of pregnancy by successive treatments with PMSG (30 IU/rat, sc on day 12) and hCG (10 IU/rat, iv on day 14), and in the second model by progesterone implants on day 15 of pregnancy. During normal pregnancy, each of the 3 PLs exhibited only one secretory peak in the serum; PL- $\alpha$ and PL- $\beta$ on day 12 and placental lactogen II (PL-II) on day 20. Interestingly, in the rats with new sets of corpora lutea, serum PL- $\alpha$ and PL- $\beta$ levels began to increase again on day 18 and showed peaks on day 20 for PL- $\alpha$ and on day 22 for PL- $\beta$. In this model, the initiation of PL-II secretion was not affected, but high levels were maintained until day 26, when parturition occurred. In rats receiving either PMSG or hCG, the secretory patterns of the PLs were similar to as those during normal pregnancy. In the progesterone-implanted rats, the second secretory peaks of PL- $\alpha$ appeared on day 20 and PL- $\beta$ on day 22. The start of secretion of PL-II was delayed for 4 days. In the progesterone-implanted rats, ovariectomy on day 15 abolished the secretions of all 3 placental lactogens (PL- $\alpha$, PL- $\beta$ and PL-II). Thus, mid-pregnancy-specific PLs, PL- $\alpha$ and PL- $\beta$, are secreted again if the period of pregnancy is extended either by the induction of a new set of corpora lutea or by progesterone implantation, and these secretions depend on the ovary.
\end{abstract}

Key words: Placenta, Placental lactogen- $\alpha$, Placental lactogen- $\beta$, Pregnancy, Ovary.

(Endocrinol Japon 38: 541-549, 1991)

THE PLACENTA plays an essential role in maintaining luteal function during pregnancy in the rat $[1,2,3]$. The main endocrine participation of the placenta is attributed to placental lactogens (PLs) [3-7], and two have been found in the serum during pregnancy [8-13]. Placental lactogen I (PL-I), a higher mol wt protein is secreted during mid-pregnancy and placental lactogen II (PL-II), a

Received: August 19, 1991

Accepted: September 20, 1991

Correspondence to: Dr. Kunio SHIOTA, Laboratory of Cellular Biochemistry, Veterinary Medical Science, The University of Tokyo, 1-1-1 Yayoi, Bunkyo-ku, Tokyo 113, Japan. lower mol wt protein, at the end of pregnancy [9-15]. We have recently reported that there are two distinct forms of placental lactogen-like substances in the fraction of PL-I activity from the serum or placental tissue in rats during midpregnancy, tentatively termed placental lactogen- $\alpha$ $(\mathrm{PL}-\alpha)$ and placental lactogen- $\beta$ (PL- $\beta$ ) (Furuyama et al., footnote). The mol wt of PL- $\alpha$ and PL- $\beta$ were estimated to be $55-60 \mathrm{~K}$ and $45-50 \mathrm{~K}$, respectively, by HPLC gel-filtration. Considering the mol wt of these PL-like substances, PL- $\beta$ seems to be identical to PL-I [13]. PL- $\alpha$ and PL- $\beta$ were found to be glycosylated proteins and their biochemical 
characteristics are distinct from other new members of the prolactin-like hormones, late rPL-like protein [15] , PRL-like protein A (PLP-A) [16, 17] and PLP-B [18], 4 growth hormone-like proteins [19] and a PL-I variant [20].

The secretory profiles of placental hormones including PLs show specific changes through pregnancy. These activities may depend on the autonomic functions of placenta considering that the placenta contains many substances such as cytokines and growth factors and hypothalamic releasing factors [21, 22]. It is, however, reported that the maternal or fetal organs including the ovaries, pituitary and adrenal glands exert an inhibitory effect on the secretion of late-pregnancy specific PL [23-25].

Little information is available on the regulation of mid-pregnancy specific PLs. This may be due to methodological problems. For example, during mid-pregnancy, the removal of endocrine organs such as the ovary induces nonspecific damage, fetal death and placental necrosis. We have employed a different approach to obtain an insight into the regulation of mid-pregnancy specific PLs secretion by using prolonged-pregnancy models. The introduction of a new crop of corpora lutea at mid- or late-pregnancy by successive administration of PMSG and hCG to pregnant rats produces prolonged secretion of progesterone from the new corpora lutea and results in a delay in the occurrence of parturition [26]. A progesterone supplement given to the animals during late pregnancy also prolongs the period of pregnancy.

In the present study, the secretory patterns of 3 PLs (PL- $\alpha$, PL- $\beta$ and PL-II) have been investigated in rats during normal pregnancy and in 2 prolonged-pregnancy models, new sets of corpora lutea-bearing rats and progesterone-implanted rats.

\section{Materials and Methods}

Animals and treatments

Adult female Wistar-Imamichi rats (Imamichi Institute for Animal Reproduction, Japan) were kept under a lighting schedule of 14-h light and

The manuscript cited in the text (Furuyama et al.) is as follows: Furuyama N, Shiota K, and Takahashi M (1991) Two Distinct Placental Lactogen-like Substances in Serum during Mid-Pregnancy in the Rat. Endocrinol Japon 38: 533-540, 1991 10-h darkness (lights on from 0500-1900 h) and fed food and water ad libitum. In the evening of the proestrous day, each female was housed with a male, and the day sperm was observed in the vaginal smear was designated day 0 of pregnancy.

\section{Rats with new sets of corpora lutea}

A new set of corpora lutea was introduced during pregnancy according to the regimen reported previously [26]. PMSG (30 IU $/ 0.2 \mathrm{ml} / \mathrm{rat}, s c)$ and hCG $(10 \mathrm{IU} / 0.1 \mathrm{ml} / \mathrm{rat}, i v)$ dissolved in $0.85 \mathrm{M}$ $\mathrm{NaCl}$ were injected between 1400 and $1600 \mathrm{~h}$ on day 12 and between 1400 and $1600 \mathrm{~h}$ on day 14 , respectively. The treated rats ovulate on day 15 and pregnancy is prolonged. For the control experiment, pregnant rats received either PMSG alone or hCG alone.

\section{Progesterone-implanted rats}

Six silastic tubes $(2 \mathrm{~mm}$ i.d., $3 \mathrm{~mm}$ o.d., $4 \mathrm{~cm}$ long) containing crystalline progesterone were implanted $s c$ between 1200 and $1600 \mathrm{~h}$ on day 14 . Some of these progesterone-implanted rats were ovariectomized between 1000 and $1200 \mathrm{~h}$ on day 15. Some rats from 6 groups (A, intact; B, new sets of corpora lutea bearing; C, PMSG-treated; D, hCG-treated; E, progesterone implanted; F, progesterone-implanted and ovariectomized rats) were sacrificed on day 20 of pregnancy, and the number and weight of the placentas and fetuses were recorded. Blood samples were collected from day 2 to the end of pregnancy at 2-day intervals from the tail vein under light ether anesthesia between 1300 and $1400 \mathrm{~h}$. Samples were kept at room temperature for $20 \mathrm{~min}$ and centrifuged at $1,500 \times g$ at $4^{\circ} \mathrm{C}$ for $15 \mathrm{~min}$. The sera thus obtained were stored at $-80^{\circ} \mathrm{C}$ for further analysis.

Sample treatment and radioreceptor assay of PLs

Before the radioreceptor assay (RRA), the serum samples were purified by ammonium sulfate precipitation and HPLC-gel filtration as described elsewhere (Furuyama et al., footnote). To serum samples $(200 \mu l)$ was added ammonium sulfate to $80 \%$ saturation, and they were centrifuged at $27,000 \times g$ for $40 \mathrm{~min}$ at $4^{\circ} \mathrm{C}$. The precipitates were dissolved in $200 \mu l$ of $50 \mathrm{mM}$ phosphate buffer ( $\mathrm{pH}$ 7.0), applied to a gelfiltration column (TSK-G3000swXL), and the PLs were eluted with $20 \mathrm{mM}$ Tris/HCl buffer $(\mathrm{pH} 7.0)$ 
containing $0.15 \mathrm{M} \mathrm{NaCl}$ at a flow rate of 1.0 $\mathrm{ml} / \mathrm{min}$ (Fig. 1). The placental lactogens were assayed by RRA for prolactin-like activity, as described previously [8, Furuyama et al., footnote]. Briefly, the receptor source was liver membrane from pregnant rats at day 16 of pregnancy. The plasma membrane was purified on a Percoll gradient [27]. The reference standard was ovine prolactin (oPRL, $31 \mathrm{IU} / \mathrm{mg}$, Sigma) and results were exprešsed as ng oPRL/ml serum. The assay buffer was $20 \mathrm{mM}$ Tris/HCl, $\mathrm{pH} 7.8$, containing 10 $\mathrm{mM} \mathrm{CaCl}_{2}$ and $1 \% \mathrm{BSA}$. A sample $(50-100 \mu l)$ or standard (0.02-62 $\mathrm{mIU}$ oPRL/tube) was mixed with $100 \mu l$ of ${ }^{125} \mathrm{I}$-rPRL $(100,000 \mathrm{cpm})(\mathrm{NEN}$ Dupont), $50 \mu l$ of the membrane suspension and an appropriate volume of the buffer to give a final volume of $300 \mu \mathrm{l}$. After incubation for $90 \mathrm{~min}$ at $25^{\circ} \mathrm{C}, 1 \mathrm{ml}$ of ice cold assay buffer was added to the reaction mixture and the preparation was centrifuged at $1,500 \times g$ for $20 \mathrm{~min}$ at $4^{\circ} \mathrm{C}$. The precipitate was washed twice with ice-cold assay buffer and the radioactivity was counted using a gamma-counter. The inter- and intra-assay coefficients of variation were $13.5 \%$ and $9.1 \%$ for PL- $\alpha, 12.8 \%$ and $8.9 \%$ for PL- $\beta$, and $15.1 \%$ and $8.7 \%$ for PL-II. The assay limit of RRA was $3.2 \mathrm{ng}$ oPRL equivalent $/ \mathrm{m} l$ serum.

\section{Hormone assays}

Progesterone was assayed by radioimmunoassay with a specific antiserum raised in a rabbit against 4-pregnen-1 $1 \alpha$-ol-3,20-dion hemisuccinate: BSA (Steraroid). The method and specificity of the antibody were described previously [28]. Intraassay coefficient of variation was $7 \%$. rPRL was assayed according to the method reported previously [29] using a RIA kit generously provided by NIADDK. The purpose of this assay was to examine if the PL activity obtained by RRA was the result of contamination with PRL. rPRL was eluted after the PL-II fraction, and no detectable PRL was found in fractions corresponding to $\mathrm{PL}-\alpha$, PL- $\beta$ and PL-II (data not shown).

\section{Statistical analysis}

The significance of differences was calculated by Duncan new multiple range test using SuperANOVA $^{\mathrm{TM}}$ (Abcus Concepts. Inc., Berkeley, CA) and application software for Macintosh ${ }^{\mathrm{TM}}$ (Apple Computer, Inc., Cupatino, CA). Differences at $p$ values of less than 0.05 were considered to be significant.

\section{Results}

Serum levels of PL- $\alpha, P L-\beta$ and PL-II during normal pregnancy

Serum samples that were subjected to TSK gel filtration (TSK-G3000swXL) had fractions that eluted at $6.5-7.5 \mathrm{~min}, 9.5-10.5 \mathrm{~min}$ and 12.5-13.5 min for PL- $\alpha$, PL- $\beta$ and PL-II, respectively, as shown in Fig. 1.

Profiles of serum PLs during normal pregnancy are shown in Fig. 2. PL- $\alpha$ and PL- $\beta$ were detectable on day 10 of pregnancy and peaked on day 12 . The levels of both PL- $\alpha$, and PL- $\beta$ fell by day 20 .

A slight and temporal increase in PL-II levels was observed on day 12 and a major rise in PL-II levels started on day 16 and continued until day 20. After delivery, there was a rapid decrease in PL-II to undetectable levels.

Serum progesterone and PLs levels in prolongedpregnancy rats with new sets of corpora lutea

Serum progesterone levels of normal pregnant and new sets of corpora lutea-bearing rats are shown in Fig. 3A. During normal pregnancy, serum progesterone peaked on day 14 and stayed at high levels until day 20. On day 21, the level decreased markedly. In the rats with new sets of corpora lutea, during prolonged pregnancy, progesterone levels were identical with those in

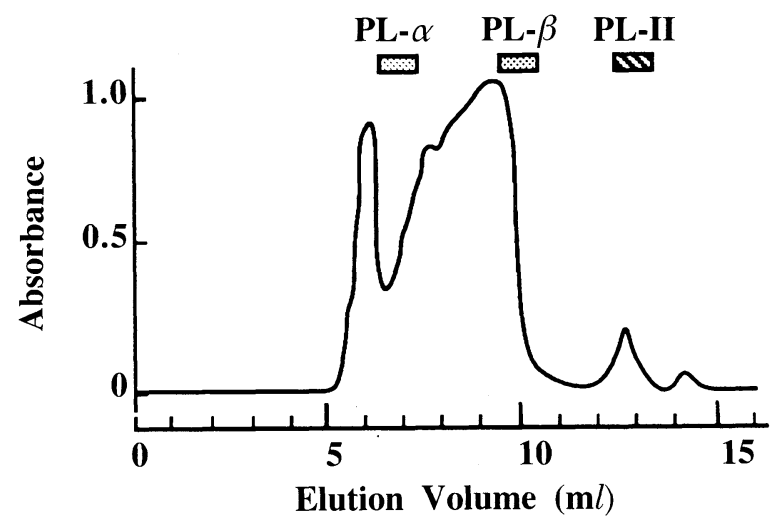

Fig. 1. Fractionation of PL- $\alpha$, PL- $\beta$ and PL-II by HPLC gel filtration (TSK-G3000swXL). PL- $\alpha$, PL- $\beta$ and PL-II were eluted at $6.5-7.5 \mathrm{~min}, 9.5-10.5 \mathrm{~min}$ and $12.5-13.5$ min, respectively. Serum sample $(200 \mu l$ equivalent precipitated with ammonium sulfate) obtained on day 12 of pregnancy was chromatographed, and absorbance at $280 \mathrm{~nm}$ was monitored. 


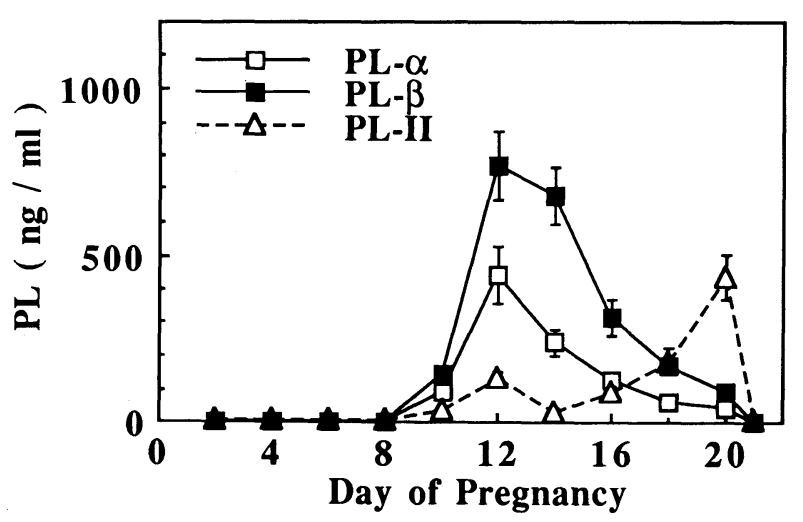

Fig. 2. Serum levels of PL- $\alpha$, PL- $\beta$ and PL-II during normal pregnancy in rats. Serum samples were treated with ammonium sulfate, subjected to HPLC gel filtration (TSK-G3000swXL) and the PL- $\alpha$, PL- $\beta$ and PL-II fractions shown in Fig. 1 were collected for RRA. Values are expressed as ng of oPRL equivalent and each point represents the mean \pm SE for 4 to 5 rats.

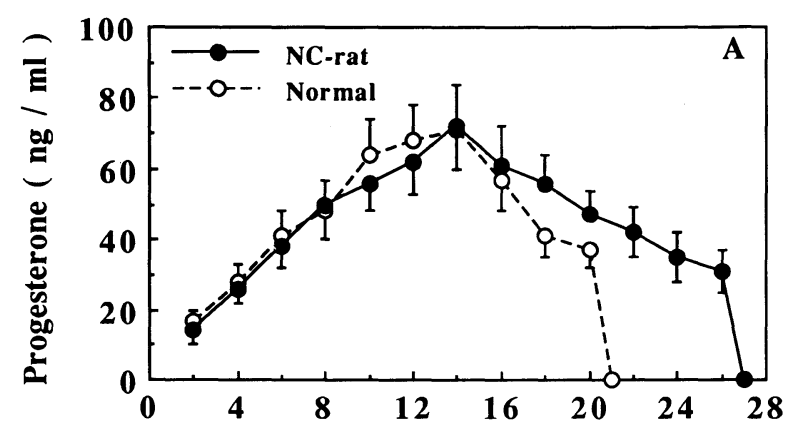

Day of Pregnancy

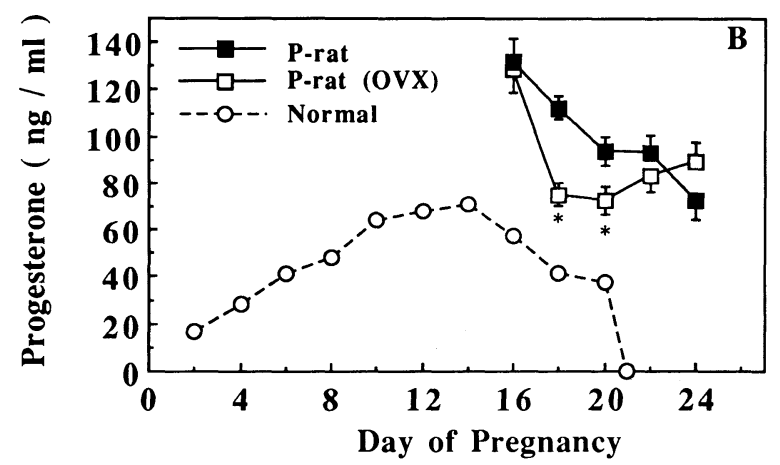

Fig. 3. Serum levels of progesterone during pregnancy in normal and prolonged-pregnancy rats with new sets of corpora lutea (NC-rats) (A) or progesterone implantation (P-rats) (B). A: The NC-rats were treated with PMSG (30 IU/rat, sc) on day 12 and hCG (10 IU/rat, iv) on day 14 of pregnancy. B: Silastic tubing, which contained crystalline progesterone, was implanted $s c$ on day 14. Some of the P-rats were ovariectomized on day 15. Each point represents the mean \pm SE for 4 to 5 rats. *, Significantly different $(\mathrm{p}<0.05)$ from P-rats.
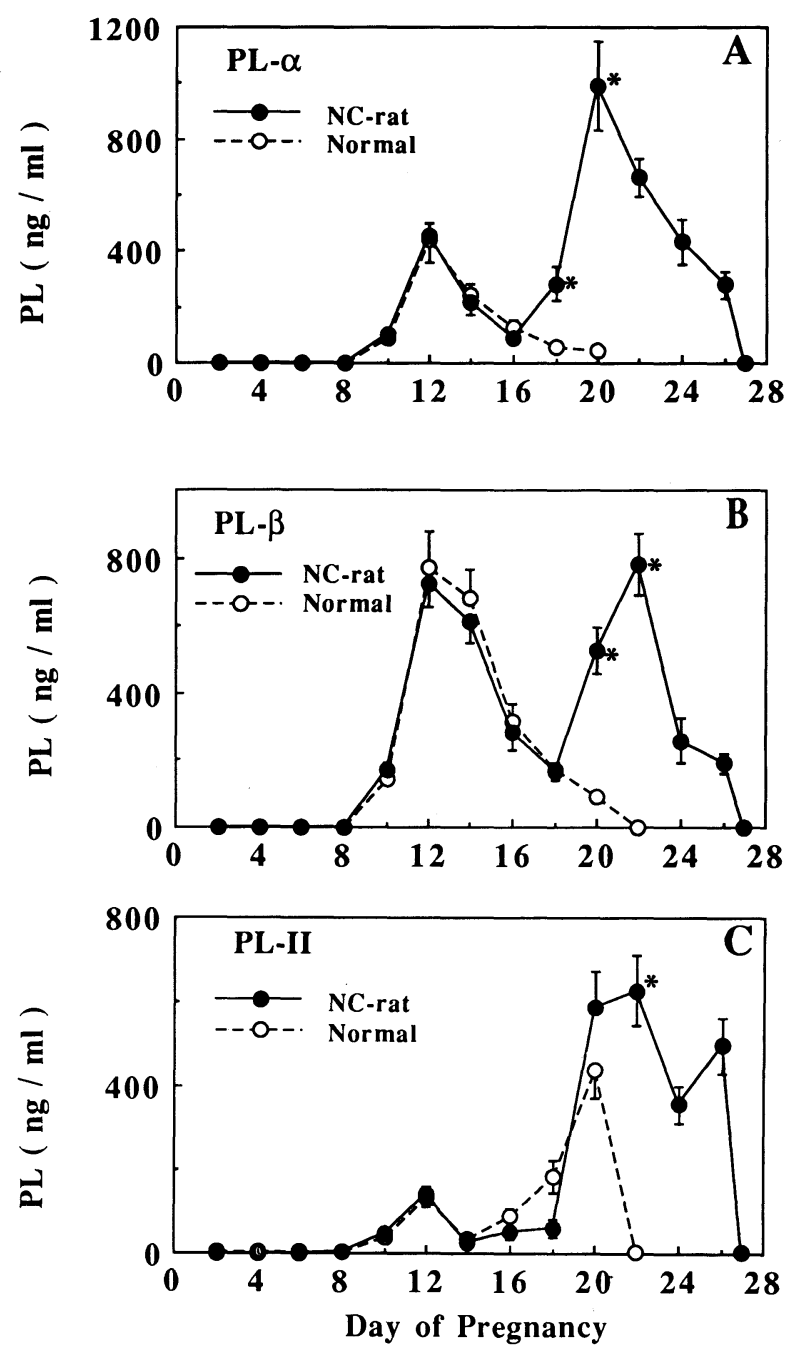

Fig. 4. Serum PLs levels in prolonged-pregnant rats with new set of corpora lutea (NC-rats). PL- $\alpha$, PL- $\beta$ and PL-II were separated by HPLC-gel filtration and assayed by RRA. The NC-rats were treated with PMSG (30 IU/rat, $s c$ ) on day 12 and hCG (10 IU/rat, iv) on day 14 of pregnancy. Each point represents the mean \pm SE for 4 to 5 rats. *, Significantly different $(p<0.05)$ from normal rat.

normal pregnant rats until day 20 . Thereafter, the relatively high progesterone levels were maintained until day 26. The duration of pregnancy in the new sets of corpora lutea bearing rats extended to days 27 or 28 , when the dams died probably due to parturition inability.

Profiles of serum PLs are shown in Fig. 4, in which the serum hormone levels in normal pregnant rats (control) are superimposed for comparison. Serum levels of PL- $\alpha$ (Fig. 4A) and PL- $\beta$ (Fig. $4 \mathrm{~B})$ in rats with new sets of corpora lutea were similar to those of normal pregnant rats until day 
16. Interestingly, the levels of both PLs increased again in the rats with new sets of corpora lutea, forming a peak on day 20 for PL- $\alpha$ and on day 22 for PL- $\beta$. The second peak concentration of PL- $\alpha$ was even higher than the first peak observed on day 12 , while that of PL- $\beta$ was at a level similar to the first peak. Though the serum concentrations decreased thereafter, the secretion of PL- $\alpha$ and PL- $\beta$ continued until day 26.

The serum levels of PL-II in normal and the rats with new sets of corpora lutea were not significantly different until day 16 (Fig. 4C). In the prolonged-pregnancy model, the PL-II concentration gradually increased, reached a plateau on day 20 and remained high until day 24.

The pregnant rats which received either PMSG or hCG alone did not ovulate and the duration of pregnancy was not extended, showing a similar PL profile to that of normal pregnant rats (data not shown).

The introduction of a new crop of corpora lutea into pregnant rats therefore gives the placenta the ability to secrete not only the late-pregnancy PL (PL-II) but also the mid-pregnancy PL-like substances (PL- $\alpha$ and PL- $\beta$ ).

Serum progesterone and PL levels in prolongedpregnancy rats with progesterone implants

The serum levels of progesterone and PLs in the rats bearing silastic tubes containing progesterone are shown in Fig. 3B and Fig. 5. By means of this treatment, the length of pregnancy in P-rats was extended as long as the dams survived and thus the length varied from day 23 to day 26. The length was not shortened if the ovaries were removed.

Serum progesterone levels in the progesteroneimplanted rats were much higher on day 16 than in normal pregnancy, and had decreased significantly by day 20 . Ovariectomy in the progesterone-implanted rats on day 15 significantly reduced the serum progesterone level by day 18 . In these groups, there was no significant difference between serum progesterone levels on day 22 and 24. The implantation of silastic tubes containing progesterone therefore maintained the serum progesterone level at about $70-90 \mathrm{ng} / \mathrm{ml}$, which is slightly higher than the peak level in normal pregnancy.

In progesterone-implanted rats, serum PL- $\alpha$ began to increase again on day 18 . It reached a
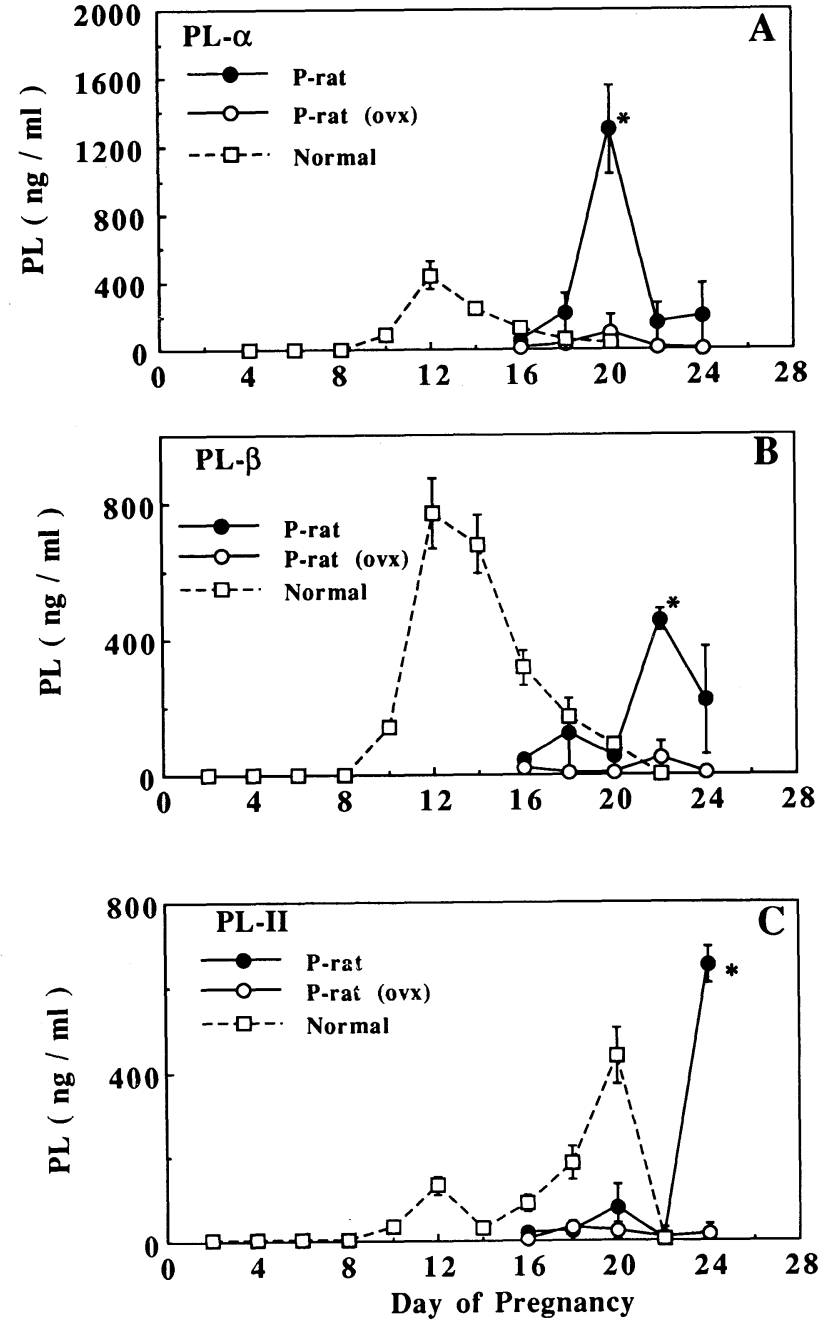

Fig. 5. Serum PL levels in prolonged-pregnancy rats with implantation progesterone tubing (P-rats). Silastic tubing, which contained crystalline progesterone, was implanted subcutaneously on day 14 . Some of the P-rats were ovariectomized on day 15 . PL- $\alpha$, PL- $\beta$ and PL-II were separated by HPLC-gel filtration and assayed by RRA. Each point represents the mean \pm SE for 4 to 5 rats. Data on day 24 in P-rats and ovariectomized-P rats were the mean for 3 rats. *, Significantly different $(\mathrm{p}<0.05)$ from normal rat and ovariectomized P-rats.

high level on day 20 (Fig. 5A) and decreased by day 22. Progesterone implantation also caused the formation of a significant second peak of serum PL- $\beta$ during the late-pregnancy period (Fig. $5 \mathrm{~B}$ ). Thus supplementation of progesterone given to pregnant rats during late pregnancy period caused additional secretion of mid-pregnancy PLlike substances (PL- $\alpha$, PL- $\beta$ ).

The initiation of PL-II release was delayed in P-rats (Fig. 5C). There was no secretion until day 
Table 1. Weights and numbers of placentas and fetuses in normal and prolonged-pregnancy rats

\begin{tabular}{lcccc}
\hline \multirow{2}{*}{$\begin{array}{l}\text { Treatments } \\
\text { groups }\end{array}$} & \multicolumn{2}{c}{ Mean no. } & \multicolumn{2}{c}{ Mean wt. (g) } \\
& Placentas & Fetuses & Placenta & Fetus \\
\hline A. Normal rats & $12.0 \pm 2.3$ & $11.8 \pm 2.5$ & $0.452 \pm 0.032$ & $5.62 \pm 0.24$ \\
B. NC-rats & $11.7 \pm 0.7$ & $10.0 \pm 0$ & $0.407 \pm 0.003$ & $5.52 \pm 0.09$ \\
C. PMSG alone & $13.7 \pm 0.9$ & $12.7 \pm 1.5$ & $0.436 \pm 0.045$ & $5.32 \pm 0.11$ \\
D. hCG alone & $13.0 \pm 1.0$ & $13.0 \pm 1.0$ & $0.416 \pm 0.045$ & $5.85 \pm 0.16$ \\
E. P-rat & $12.3 \pm 0.7$ & $12.3 \pm 0.7$ & $0.385 \pm 0.027$ & $5.76 \pm 0.45$ \\
F. P-rat, OVX & $10.0 \pm 0.6$ & $9.7 \pm 0.9$ & $0.407 \pm 0.021$ & $5.95 \pm 0.10$ \\
\hline
\end{tabular}

In group B, a new set of corpora lutea were introduced by successive treatments with PMSG (30 IU/0.2 $\mathrm{ml} / \mathrm{rat}$, sc) on day 12 and hCG (10 IU/0.1 $\mathrm{m} l / \mathrm{rat}, i v)$ on day 14 of pregnancy. In groups $\mathrm{C}$ and $\mathrm{D}$, pregnant rats received either PMSG or hCG alone. In groups $\mathrm{E}$ and $\mathrm{F}$, progesterone tubes were implanted $s c$ on day 14 . In group $\mathrm{F}$, rats were ovariectomized on day 15. All these rats were sacrificed on day 20 , and the number and weight of the placentas and fetuses were recorded. Values are the mean $\pm \mathrm{SE}(\mathrm{n}=3-4$ of dams). There was no significant $(\mathrm{p}>0.05)$ difference between normal and other groups.

22 , but levels rose by day 24 in all surviving dams $(3 / 4)$.

Ovariectomy in P-rats on day 15, the day after progesterone implantation, completely diminished the second rise in PL- $\alpha$ and PL- $\beta$. Moreover, PL-II secretion expected to occur at the end of the pregnancy period was also completely diminished.

Weight and number of placentas and fetuses in the new sets of corpora-bearing rats and progesterone-implanted rats

The weight and number of placentas and fetuses on day 20 of pregnancy were recorded (Table 1). The numbers and weights of placentas and fetuses in the rats with new sets of corpora lutea and progesterone-implanted rats were similar to those of normal pregnant rats, and there was no significant difference in the weight of placentas in progesterone-implanted rats.

\section{Discussion}

We have confirmed the results of our previous studies indicating that there are two distinct PL-like substances named PL- $\alpha$ and PL- $\beta$ in the serum of rats at mid-pregnancy (Furuyama et al., footnote). In the present study, we have found that these PL-like substances were secreted again if the pregnancy period was extended by either the introduction of a new crop of corpora lutea or progesterone implantation. Although the secre- tory profiles of PL- $\alpha$ and PL- $\beta$ are not clearly dissociated from each other during normal pregnancy, they have different profiles during the second secretory period, suggesting that they are individually controlled. Extended pregnancy also prolonged the PL-II secretory period. The shifting of PL-like substances secretion from midpregnancy specific PL-like substances (PL- $\alpha$ and PL- $\beta$ ) to late-pregnancy specific PL (PL-II), which occurs during normal pregnancy, is therefore not only due to intra-placental changes, but is also conditioned by a maternal endocrinological milieu.

Progesterone is not the primary factor necessary for the secretion of PLs, because ovariectomy in progesterone-implanted rats, in which a high level of progesterone was maintained after ovariectomy, ceased to secrete all PLs. Since treatment with PMSG alone, which induces follicular growth and estradiol production, did not induce the secretion of these hormones, the absence of PLs secretion after ovariectomy cannot be attributed to deprivation of peripheral estradiol. The secretory patterns of all the placental lactogens examined were affected by neither PMSG alone nor hCG alone. The combination of both treatments induced ovulation, thus degrading the original crop of functional corpora lutea and introducing a new crop of corpora lutea [26]. Therefore, it is thought that the change in PLs secretions occurring in the two models of prolonged pregnancy depends on a qualitative change in ovarian function, but is not 
related to the direct action of PMSG and/or hCG on the placenta.

Tonkowicz and Voogt [24] have investigated the role of ovarian steroids in the secretion of midpregnancy PL. They showed that ovariectomy on day 10 caused a marked fall in PL activity between day 11 and day 14 of pregnancy, and that treatment with progesterone or progesterone plus estrogen restored secretion of PL activity by half of that in intact rats. Steroids themselves did not seem to be a primary factor responsible for the release of PL- $\alpha$ and PL- $\beta$ in the present study. In their experiments, they dealt with placentas from an earlier period in pregnancy. The ovarian steroids were shown to be involved in the regulation of placental growth [30-33] which is active during mid-pregnancy. Therefore, progesterone or/and estrogen may be important for placentas to develop the capacity to secrete PL-Is.

Ovariectomy inhibited the abrupt appearance of PL-II in peripheral circulation suggesting that the ovary is also necessary for the secretion of PL-II. Robertson et al. [25], on the other hand, showed that ovariectomy of pregnant rats on day 14 to 16 resulted in a rapid increase in serum PL-II levels, and that supplementation with progesterone or progesterone plus estrogen maintained the levels intact until day 21. In this stituation [25], if the ovary is removed or the steroid treatment is withdrawn, abortive process of pregnancy should certainly start. In our study, however, the maintenance of pregnancy itself was secured by progesterone implants before ovariectomy had been performed.

It is reported that fetuses are necessary for the normally observed increase in PL-II secretion [23]. The sustained secretion of PL-II observed in our prolonged pregnancy models may be at least partly due to the extended presence of fetuses. Interestingly, the secretion of PL-II was suppressed in the progesterone-implanted rats until day 22 , though the number of living fetuses was normal on day 20 of pregnancy. Therefore, a high level of progesterone seems to inhibit the start of PL-II secretion, probably because such as level of progesterone blocks the initiation of parturition. If we assume here that some factor associated with the abortive or parturitional process during late pregnancy triggers the secretion of PL-II, the discrepancy between the findings of Robertson $e t$ al. [25] and ours would be reconciled.

In contrast to the luteotrophic activity in serum from mid-pregnancy [3, 4, 6, 34], serum from rats at day 19, expected to contain PL-II, exhibited no luteotrophic activity [34]. Moreover, there was a reciprocal relationship between serum progesterone and PL-II levels; serum progesterone started to decline from day 16 to day 18 and decreased markedly from day 20 to day 21 immediately before the occurrence of parturition in normal pregnancy. Also, in the rats with new sets of corpora lutea, progesterone levels fell from day 16 to day 26 , although not to such a marked degree as in normal pregnant rats. Therefore, PL-II may be luteolytic rather than luteotrophic. If this is the case, the prolongation of pregnancy in rats with new sets of corpora lutea may be due to countering of the luteolytic action of PL-II by the luteotrophic effects of PL- $\alpha$ and PL- $\beta$. The exact role of each of these hormones remains to be elucidated after their complete purification has been achieved.

In summary, mid-pregnancy-specific PL-like substances, PL- $\alpha$ and PL- $\beta$, are secreted again during late pregnancy if the period of pregnancy is extended. This second secretion depends entirely on factors from the ovary, either by the induction of a new set of corpora lutea by successive treatments with PMSG and hCG or implantation of progesterone. The second secretion of PL-like substances in progesteroneimplanted rats was abolished by ovariectomy. The results of our investigation indicate that the ovary is involved in the stimulatory mechanism of PL- $\alpha$ and PL- $\beta$.

\section{Acknowledgments}

We thank Dr. A. F. Parlow and NIADDK for rPRL RIA materials, and Dr. D. B. Douglas for proofreading the manuscript. This work was supported in part by a grant from the Ministry of Education, Science and Culture, Japan. 


\section{References}

1. Astwood EB, Greep RO (1938) A corpus luteum stimulating substance in the rat placenta. Proc Soc Exp Biol Med 38: 713-716.

2. Ray EW, Averill SC, Lyons WR, Johnson RE (1955) Rat placental hormonal activities corresponding to those of pituitary mammotropin. Endocrinology 56 : 359-373.

3. Matthies DL (1969) Studies of the luteotropic and mammotropic factor found in trophoblast and maternal peripheral blood of the rat at midpregnancy. Anat Rec 159: 55-68.

4. Cohen RM, Gala RR (1969) Detection of luteotropic and mammotropic activity in the serum of rats at midpregnancy. Proc Soc Exp Biol Med 132: 683-685.

5. Shin JG, Eto T, Hashimoto I, Suzuki Y (1971) participation of pregnant uterus upon the gestagen secretion during midpregnancy in the rat. Endocrinol Japon 18: 495-500.

6. Linkie DM, Niswender GD (1973) Characterization of rat placental luteotropin. Biol Reprod 8: 48-57.

7. Morishige WK, Rothchild I (1974) Temporal aspects of regulation of corpus luteum function by luteinizing hormone, prolactin and placental lactogen during the first half of pregnancy in the rat. Endocrinology 95: 260-274.

8. Shiu RPC, Kelly PA, Friesen HG (1973) Radioreceptor assay for prolactin and other lactogenic hormones. Science 180: 968-971.

9. Kelly PA, Shiu PRC, Robertson MC, Friesen HG (1975) Characterization of rat chorionic mammotropin. Endocrinology 96: 1187-1195.

10. Robertson MC, Friesen HG (1975) The purification and characterization of rat placental lactogen. Endocrinology 97: 621-629.

11. Kelly PA, Tsushima T, Shiu RPC, Friesen HG (1976) Lactogen and growth hormone-like activities in pregnancy determined by radioreceptor assay. Endocrinology 99: 765-774.

12. Robertson MC, Friesen HG (1981) Two forms of placental lactogen revealed by radioimmunoassay. Endocrinology 108: 2388-2390.

13. Robertson MC, Gillespie B, Friesen HG (1982) Characterization of the two forms of rat placental lactogen (rPL): rPL-I and rPL-II. Endocrinology 111: 1862-1866.

14. Duckworth ML, Kirk KL, Friesen HG (1986) Isolation and identification of a cDNA clone of rat placental lactogen II. J Biol Chem 261: 1087110878.

15. Robertson MC, Croze F, Schroedter IC, Friesen HG (1990) Molecular cloning expression of rat placental lactogen-I complementary deoxyribonucleic acid. Endocrinology 127: 702-710.

16. Duckworth ML, Peden LM, Friesen HG (1986)
Isolation of a novel prolactin-like cDNA clone from developing rat placenta. J Biol Chem 261: 10879-10884.

17. Deb S, Youngblood T, Rawitch AB, Soares MJ (1989) Placental prolactin-like protein A. J Biol Chem 264: 14348-14353.

18. Duckworth ML, Peden LM, Friesen HG (1988) A third prolactin-like protein expressed by the developing rat placenta: complementary deoxyribonucleic acid sequence and partial structure of the gene. Mol Endocrinol 2: 912-920.

19. Ogilvie S, Buhi WC, Olson JA, Shiverick KT (1990) Identification of a novel family of growth hormone-related proteins secreted by placenta. Endocrinology 126: 3271-3276.

20. Deb S, Faria TN, Roby KF, Larsen D, Kwok SCM, Talamantes F, Soares MJ (1991) Identification and characterization of a new member of the prolactin family, placental lactogen-I variant. $J$ Biol Chem 266: $1605-1610$.

21. Talamantes F, Ogren L (1988) The placenta as an endocrine organ: polypeptides. In: Knobil E, Neil J (ed) The Physiology of Reproduction. Raven Press, New York, 2: 2093-2144.

22. Ringler GE, Strauss JF (1990) In vitro systems for the study of human placental endocrine function. Endocrine Rev 11: 105-123.

23. Robertson MC, Owens RE, McCoshenJA, Friesen HG (1984) Ovarian factors inhibit and fetal factors stimulate the secretion of rat placental lactogen. Endocrinology 114: 22-30.

24. Tonkowicz PA, Voogt JL (1984) Ovarian and fetal control rat placental lactogen and prolactin secretion at midpregnancy. Endocrinology 114: 254-259.

25. Robertson MC, Owens RE, Klindt J, Friesen HG (1984) Ovariectomy leads to a rapid increase in rat placental lactogen secretion. Endocrinology 114: 1805-1811.

26. Takahashi M, Shiota K, Suzuki Y (1979) Introduction of a new crop of corpora lutea during pregnancy and its effect on luteal function and parturition in the rat. Biol Reprod 21: 813-822.

27. Belsham GJ, Denton RM, Tanner MJA (1980) Use of a novel rapid preparation of fat-cell plasma membranes employing Percoll to investigate the effects of insulin and adrenaline on membrane protein phosphorylation within intact fat cells. Biochem J 142: 457-467.

28. Matsuyama S, Shiota K, Takahashi M (1990) Possible role of transforming growth factor- $\beta$ as a mediator of luteotropic action of prolactin in rat luteal cell cultures. Endocrinology 127: 1561-1567.

29. Shiota K, Takahashi M, Masaki T, Sudo K (1989) Calcium metabolism, serum thyroid-stimulating hormone, prolactin, and growth hormone in spon- 
taneously hypercholesterolemic rats. Proc Soc Exp Biol Med 190: 229-233.

30. Csapo AI, Wiest WG (1973) Plasma steroid levels and ovariectomy-induced placental hypertrophy in rats. Endocrinology 98: 1173-1177.

31. Csapo AI, Wiest GW (1969) An examination of the quantitative relationship between progesterone and the maintenance of pregnancy. Endocrinology 85: 735-746.

32. Csapo AI, Dray F, Erdos T (1975) The biological effects of injected antibodies to estradiol- $17 \beta$ and to progesterone in pregnant rats. Endocrinology 97 : 603-614.

33. Ichikawa S, Nakamura Y, Sawada T (1982) Effect of corpora lutea on placental hypertrophy in rats. J Endocrinol 92: 43-49.

34. Glaser LA, Kelly PA, Gibori G (1984) Differential action and secretion of rat placental lactogens. Endocrinology 115: 969-976. 